\title{
REGIONAL LITERATURE AND STREAKS OF MARGINALIZATION: AN OVERVIEW OF GUJARATI DALIT LITERATURE
}

\author{
Dr. Preeti Oza \\ St. Andrew"s College \\ University of Mumbai
}

\begin{abstract}
An overview of Gujarati Lalit (mainstream literature, having derived the name from its obsession with the „beautiful") clearly indicates the predominant presence of Brahmin writers. It is against this backdrop of Gujarati Lalit literature, considered central/ mainstream, great/ aesthetic, that Dalit literature came to be considered marginal/ peripheral, little/ unaesthetic. These two currents are fundamentally oppositional. It is out of this situation that Dalit literature begins to define itself as being essentially different in nature, scope, implications, and direction.
\end{abstract}

Like other Dalit writings, Gujarati Dalit literature is also the product of a revolt against the age-old exploitation and torture of the Gujarati upper castes. Literally, it is a revolt against decadent Modernism in Gujarati Literature. Like other parts in India, Gujarati Dalit literature was also determined and guided by the Dalit Movements in Gujarat. The movement provided a platform for Dalit writers whose creativity received no attention from a parochial literary establishment. There were some attempts to insist upon a commitment to the Movement as the first pre-requisite for a Dalit writer. But gradually, after initial hiccups, it settled in a steady and strong protest against the set system of collective injustice.

In Gujarati Literature the Dalit literary trend has started around 1975. This literary trend fully flowered after 1980. Various events and causes which took place at that time like Anti-Reservation and Anti-Roster Strikes, Communal Riots, embracing other religion, Dalit killings of Ranamalpur and Golana are responsible for this upsurge. In the $8^{\text {th }}$ decade, in the mainstream Gujarati literature, conscious literary creators of the Dalit society have started to create, as a part of the Ambedkarite movement the Dalit poems of social sensibility. That proved very significant event. These poems gave the new freshness to the Gujarati Literature.

The actual beginning of Gujarati Dalit literature can be traced back in 1975, with the launch of "Panther", edited by Rameshchandra Parmar. It was followed by a number of publications, the major amongst them were „Akrosh", „KaloSooraj", „Garud", „Dalit Bandhu“,

„Naya Marg" and „Disa". The first collection of Dalit poetry, „Dalit Kavita", edited by Ganpat Parmar and Manishi Jani was published in 1981. Immediately after this, a controversial collection called „Visphot"- edited by Balkrishna Anand and Chandu Maheria was published. In 1983, another collection named „Asmita" was brought out by Gujarat Khet Vikas Parishad. This was based on a collection of poems published in a Dalit periodical "Naya marg" between 1981 and 1983.

Like other regions of India, In Gujarat also Dalits were mainly from scheduled castes, scheduled tribes, and other backward classes. as per 1991 census, the total number of Scheduled Castes in Gujarat was around three million, i.e. approximately 7.4 percent of the total population. This makes Dalits significant strata of Gujarat population. Most of these caste groups now do not follow their traditional occupation. However, the hierarchical ranking amongst them, between them and caste Hindu persists in overt and covert forms. In economic and numerical terms the Vankars (weavers) are the strongest Dalit community. They are followed by Chamaars, also called Valmikis. There are other small groups like Senvas, Turies, Nadias, Garos, paisis, Turi-Barots, Tidgar, and others. The combination of a high degree of urbanization especially after the pervasive presence of the textile mills of Ahmedabad in the twentieth century and opportunities of education have made vankars a privileged group. The vankars also show a high rate of conversion to Christianity which has contributed to their economic and social standing.

There are many new literary and social trends visible in Gujarati Dalit literature. Gujarati Novel started with „Karan Ghelo" in 1866. But even before that, a French novel

"Chaumiere Indienne" has explained the contemporary social condition of untouchables in India. In modern Gujarati literature, Dalit writings entered with many other new literary flows. But it was never an accidental entry. Dalit literature in Gujarati literary scene entered with a specific purpose. In neighboring Maharashtra, it was an old entrant. Marathi Dalit ideology was framed out of life sketches of Dr. Babasaheb Ambedkar and Jyotiba Phule. But Gujarati Dalit literature never had a privilege to have such powerful leaders. On the other hand, even Gandhian ideology also could not influence Gujarati Dalit literature.

After the Independence, a heavy influence of Gandhi was prevailing in Gujarat for a long period. But many people felt that Gandhian Ideology was a hindrance to the development of Dalits. the reason is - the burning questions in Dalits" lives- untouchability inequality, oppression, pain, grief, and poverty are still there. 


\section{GAP BODHI TARU -}

\section{An International Peer-Reviewed \\ Open Access Journal of Humanities}

During 1975, the problems like violence against Dalits increased and some cruel instances had shattered Dalits across the country. After some years in 1981, when the Anti- Reservation movement started, it proved a catalyst to Dalit movements. Social, cultural and political equations were stirred. Even though Dalits were Hindus, their consistent neglect has led them to the crisis of identity and self-respect.

Like any other marginal literature, Gujarati Dakit literature is a collective effort and assertion of humanism. It does not talk only for the caste Dalits but other similar strata of the society who are in need of voice and justice. As neerav Patel rightly remarks, "I wish you to be not only my reader but also an empathizer, then and only then perhaps my pain would end."1

In the political arena of Gujarat, this crisis has created positive ripples. Social, political and cultural awareness among Dalits entered in their literature also. Gujarati Dalit literature has contributed in various forms like poetry, short stories, novels, life-sketches, drama, autobiography, memoires etc. But the most prominent and significant forms were short stories and novels. Dalit novels are different from Dalit short stories. A short story provides balance to a single moment or a single part of a life. A novel remains on a wider platform and keeps expanding its boundaries. The background is very important in a Dalit novel. Here the author uses all the problems in a Dalit life as material and then twists the story around it.

In Gujarat, after 1975, not only Dalits, but other non-Dalit writers also have contributed significantly toward Dalit sensitivity. In 1978, the first Gujarati Dalit Poetry was published in the magazine form. It was the first beginning of formal Gujarati literature. It was a very obvious influence of the neighbor state, Maharashtra. Some of the major writes contributed in it are Neerav Patel, Dalpat Chauhan, Pravin Gandhi, Yogesh Dave was on- Dalits. After some time Ganpat Parmar along with Manishi Jani published the first anthology of Gujarati Dalit literature. Some of the major writers in Gujarati Dalit literature are Sahil Parmar, Joseph Macwan, Dalpat Chauhan, Neerav Patel, Harish Mangalam, Pathik Parmar, Mohan Parmar, Madhukant kalpit, B.n.Vankar etc.

As K. M. Sherrif observes;

"Dalit writing has been described as one of the manifestations of Postmodernism in Indian literature. However, the acquisition of postmodernist idiom, modes and attitudes have not been uniform in Gujarati Dalit literature."2

The collective assessment of Gujarati Dalit literature and its sharp sense of ridicule can be seen in the following references.

Raju Solanki writes in his poem „Enclosure:

" Today watching my unstrained expressions. On the stone inscriptions of the time He says your poetry is an enclosure. I stare. At the wild cacti

Spread all over his face. I became a man. Upright. A thunder piercing the void That stretches from sky to earth. My cry frightened him and

Laughter stunned. He took my struggle

Against the system of the enclosure. As a challenge to his very existence And again he confined me to an enclosure. Now how can I ask

My hands which. Rise to clear the cactus wall Behold, for the sake of man"

Gujarati Lalit ( mainstream „beautiful") literature was predominantly occupied with notions of „purity", „pleasure", and „aesthetics", having grown out of the legacy of Sanskrit literature in its initial stage in the Medieval age. writers in this age were chiefly saints ( bhakti Poets) who wrote poetry on devotional and philosophical themes. Like all devotional literature, the literature of this phase was God-centric. Glorification of divinity was privileged over human emotions, thoughts, and imagination.

Modern Gujarati language, as spoken and used in literature today, is also derived from Sanskrit through the intermediate stages of Saurseni Prakrit and Gurjar Apabramsa. Like all major languages of northern and central India, Gujarati belongs to the Ind0-Aryan family of the languages. During the rule of Gurjars ( probably a Shaka tribe which entered India in the fifth century $\mathrm{AD}$ and conquered west Rajasthan and most of present-day north Gujarat by the end of the sixth century), the land came to be known as Gujarat or Gurjar Desha. The term

„Gujarat" emerged by the tenth century. The period of old Gujarati, beginning in the twelfth century, has many long narrative poems by Jain saints. The medieval period (1450-1850)is a long stretch comprising several historic changes in Gujarati literature. A plethora of poetic forms invented by the saints like Narsinh Mehta, Akho, Dayaram, and Premanad make this period an extremely fertile one.

\footnotetext{
${ }^{1}$ Nirav Patel, Tr. M.B.Gajjan. “Gujarati Dalit Poetry” in „Dalit Literature: A Critical Exploration“, Sarup and Sons, New Delhi. 2010. P- 141

${ }^{2}$ K. M. Sherrif, 'Eklvyas with Thumbs', Pushpam Publications, Ahmedabad, 1999, p-9
} 


\section{GAP BODHI TARU -}

\section{An International Peer-Reviewed \\ Open Access Journal of Humanities}

Akha"s Chhapas (a terse stanzaic form) is satiric in nature, mocking the blind and polytheistic practices of his time. Mira Bai's love poems for Krishna also belong to this period. Narmad and Dalpatram in the nineteenth century mark the „modern" phase of Gujarati literature. The first historical novel, Nandshankar Mehta"s „Karan Ghelo"(1866), and the first social novel, Mahipatram“s „Saasu Vahu ni Ladai" (1866) also belong to this phase.

These early novels serve a classic example of the hybrid ways in which the novel form was appropriated to suit local needs and narrative traditions. Here comes a very important landmark in Gujarati Literature, Goverdhanram Tripathi"s „Saraswati Chandra" (1855-1907). It is considered a transition fro the old to the modern narratives. It also provides the framework and themes for the twentieth-century novel. After "Saraswati Chandra", Gujarati novel got a good momentum. It was followed by K.M.Munshi"s fictions. He was influenced by Alexander Dumas which is visible in his trilogy of novels: „Patan ni Prabhuta" (1916), „Gujarat no Nath" (1919), „Rajadhiraj” (1922). These novels provided much-needed content to satisfy modern Gujarati reader- history, fantasy, romance, Puranic stories and above all thrillers. They have entertained many generations with fast-moving plots and put Gujarati literature in the sub-national arena.

The following period in Gujarati literature is considered a golden period. Jhaverchand Meghani took the readers to a specific region with his novel „Sorath Taara Vaheta Paani" (1937) which was the first regional novel. His contemporary Panna Lal Patel continued his tradition of the regional novel and perfected the „art" of being earthy and artless. This tradition found further sustenance with Raghuvir Chaudhari and Joseph Macwan in the seventies and eighties respectively.

The chronology of the milestone in Gujarati fiction is complex with many ideological shifts within the genre. Here Dalit literature came into existence, not as a literary phenomenon but more of a social phenomenon. Gujarati Dalit writings got a better response in the last decade of the $20^{\text {th }}$ century. Before that, it was a stony silence. As Achyut Yagnik observes;

"This graduated to a more animated discussion in the nineties especially focusing on the difference between „lait" ( Aesthetic) and „Dalit" writing. The unbridgeable gap between the aesthetic and the ideological (as two mutually exclusive or rather, inimical categories) safely kept Dalit literature out of canonizing processes as far as Gujarat was concerned."3

Gujarati Dalit literature in its first phase became synonymous with Dalit poetry as it were and the themes that inspired Dalit poets to wield their pens were revolt, protest, revenge, resentment and disgust against upper caste oppression and exploitation, unjust and enslaving social customs and traditions, most importantly the appropriation of these by the upper castes.

As kancha Ilaih notes:

" Africans, whose beauty the Dalit Bahujan of India shares, have taught us that „black is beautiful", but what we learnt from our own experience is that unless we also say that

„white is ugly", at least till the beauty of all human colors is universally recognized, no white person is going to listen to what we say. Since beauty and ugliness are both culturally constructed notions that gradually transform our consciousness, it is important that these notions be recast to change the hegemonic relations that have been brought into force in the process. Until this painful phase of inequalities has passed, and the consciousness that only the dominating groups are beautiful and others are ugly, the condemned must learn to condemn the others."

In the mainstream Gujarati literature, the political or social forces have not influenced the literary nature of the works like other languages. Marked by middle-class gentleness, the Gujarati literati squirms at apparently "crude" admissions of the subterranean life. For this reason, the reception accorded to Joseph Macwan"s „Angaliyat" demands special attention.

In Gujarati Dalit novels, realism is a predominant mode. It natural considering the fact that it is universally accepted as the most effective mode for depicting lives and times vividly and comprehensively. Joseph Macwan, the first Gujarati Dalit writer to receive a Sahitya Akademy award is a realist par excellence. Fiction and real life over-lap in his works. Many of his stories read much like his life sketches. Macwan"s style and treatment are simple but sensitive and evocative. Macwan, the author of "Angliyat" ( the Step Child"), one of the three most acclaimed novels in the history of Gujarati Literature passed away in 2010. With him departed an era of Dalit literature, for he defined, and dominated its idiom for many years. One of the most arresting storytellers of our times, Joseph"s work was dramatic, weaving tales through memory and music, breaking into elegiac songs (Marashiya), or bringing gentle flirtation through wedding songs. Like his character in the novel, Bhavan Bhagat, Joseph Macwan was a community archive, storing in his narratives the life and times of Vankar (weaver) community he belonged to. Painting with words of aspirations and tragic losses of the untouchables in his novels, he created a vivid ethnography of a region, people, and caste.

As Joseph Macwan writes in the preface of „Asmita";

\footnotetext{
${ }^{3}$ Achyut Yagnik, „Step Child“, Oxford University Press, New Delhi, 2004, P -13

${ }^{4}$ Ilaih, Kancha'Productive Labour. "Consciousness and History: The Dalitbahujan Alternative'." Subaltern Studies IX: Writings on South Asian History and Society: 165-200.
} 


\section{GAP BODHI TARU -}

\section{An International Peer-Reviewed \\ Open Access Journal of Humanities}

"The poet of the Dalit poems is conscious of his own pains-sufferings. The borrowed things he cannot digest, he has to fix the firmly fixed web of the orthodoxy. That"s why whatever is in the hand is the best weapon that is his policy; his art is that where he can use his hand. His miseries are immeasurable even the length of the epic is short to narrate that and „Khand kavyo ( long narrative poems) based on his life"s sufferings are numerous, to destroy every orthodox tradition from the source is his inscription that"s why this is not acceptable for the Dalit poetry and the poet to depart from the right path."

As Rita Kothari puts it in the first preface to the English translation of his "Angaliyat (stepchild)";

"A ray of hope, a beacon for the nascent body of writing, the community of writers, readers and critics had looked forward to Josephbhai giving direction and bringing in a freshness to Dalit writing in Gujarati, in a way that only he could have. However, some of his contemporaries believe that Josephbhai did not go beyond the personal universe to justify his claim that he was the representative voice of Gujarati Dalit writing. The matter remains contestable. Meanwhile, Josephbhai carried the burden of representation and became a symbol of both Dalit aspirations and disappointments." 6

„Angaliyat" marked a turning point for both mainstream and Dalit Gujarati alike although their perspectives are far from similar. The literary elites hailed it as an authentic voice from rural Gujarat, heard a good forty years after Pannalal Patel"s „Manavi ni Bhavai“ ( original 1947, „Endurance: A Droll saga“, Sahitya Akademy, 1995). Patel“s novel had depicted the human predicament of rural peasants during the worst famine (popularly remembered as „chhappaniyo") around 1899-1900.

In fiction, realism appears to be the predominant mode. It 1 is natural, considering the fact that it is universally accepted as the most effective mode for depicting lives and times vividly and comprehensively. Joseph Macwan is a realist par excellence. Fiction and real life overlap in his works. Many of his stories read like his life sketches collected in "Vyatha na Vitak" ( Agonies of Grief). Macwan"s style and treatment are simple but sensitive and evocative. One finds his works beyond conventional realism and explores new methods and techniques to work out a more dynamic manner of perceiving reality. In a limited span of Gujarati Dalit prose ( in all, there are not more than a couple of dozen novels and a few hundred short stories), Macwan portrays a comprehensive picture of Dalit life in Gujarat. In diligent, all-embrassing portrayal of social life, in vivid characterization and flair for detail, they can be compared with the work of the French Realists and naturalists of the Nineteenth Century.

In the arena of Gujarati literature, Joseph Macwan and his works carry a special significance. The emergence and response to „Angaliyat" (stepchild) should be contextualized to the contemporary history. Gujarati literary history has a particularly long phase of the Gandhian period- extending from the early twenties to the 1950s. the most well-known writers such as Sundaram, Umashankar Joshi, and Ishwar Petlikar are major faces of this phase. Gandhian idealism and piety provided the common touch to the literature of the Gandhi years and oriented literary commitment towards society. However, Gandhi"s refusal to delink the moral from the social and political left a distinct mark on Gujarati literature and undermines its possibilities to active and confrontational politics. This shadow continues to linger in Gujarati literature and blunts the edge of even the socalled protest literature. But it was an effort to relate to the mass communication for Gandhi and that mass was more or less the elites and the upper castes. It also provided a strong relationship between the writers as an individual to the readers.

In the 1960s and 1970s, Gujarati literature came under the heavy influence of European symbolism and existentialism. In the meantime, the movement of Progressive Writers who were influenced by the Marxist philosophy also came into limelight. Thus, if one wants to analyze historically, Gujarati literature had never been through that so-called literary activism. This was very well exposed in the $22{ }^{\text {nd }}$ conference of the Gujarati Sahitya Parishad when Rasiklal Parikh, in his presidential address mentioned about the rootlessness and fractured relationship between the writers and their public. He comments: „Even when the subject matter is related to the depressed classes of society, it does not originate directly from

them but is based on the reading of western depiction of such oppressed classes".

Unlike Marathi Dalit literature, Gujarati Dalit literature had a delayed beginning. Gujarati Dalit writings did not get any support from any large-scale political movement like Marathi Dalit literature. As mentioned earlier, during 1981, the Anti- reservation movement provided that support. The eventful year of 1981 and its consequent antireservation agitation created an environment of hostility and acrimony between upper-caste Gujaratis and Dalits. the very same environment was also helpful in evolving a Dalit literary movement, which was up until then,

\footnotetext{
${ }^{5}$ Joseph macwan, Preface, „Asmita“, ed. Chandu Meheria, Gujarat: Khet Vikas parishad

${ }^{6}$ Rita Kothari, 'Step Child', Oxford University Press, New Delhi, 2004, P -34
} 


\section{GAP BODHI TARU -}

scattered and disorganized. When „Angliyat (Step Child) was published, Gujarat was passing through this critical phase of its social history.

After the two violent anti-reservation agitations, one in 1981 and the second in 1985, the social divide between the Savarna (upper caste Hindus) and Shudras (Dalits and Tribals) was almost complete. Dalits remained the main target during both the agitations. But this left Dalits with deep humiliation and a deep sense of victimization. A small number of educated Dalits felt completely misfit on both the sides and remained isolated and alienated. The more articulate among them became increasingly inward-looking and their search for self-identity led them to deeper explorations of their own collective past. In this intense identity crisis, a new Dalit discourse was articulated. It incorporated Dalit history, Dalit sociology and above all, Dalit writings by Dalit writers. The first anthology of Dalit short stories by Parmar and Manglam was published in 1987.

Between the 1970s and 1980s, some attempts were made by some writers who were influenced by neighboring Maharashtra. Inspired by the Dalit Panthers of Mumbai, in Ahmedabad also some youth who were believers of Ambedkar started a similar organization and started publishing a magazine called „Panther" in 1975. It was the first attempt to free Dalit voices from the clutches of the mainstream literature. Encouraged by the great response to Dalit poems published occasionally in the magazine, they started writing Dalit prose in the form of short stories. The term „Dalit" also started getting recognition and more and more people of different low caste communities started replacing it with other terms like „Harijan“. The search for assertive identity, on the lines of Dr. Ambedkar"s teaching, played a major role in the acceptance of this term.

Dalit Panthers established a poetry magazine named „Akrosh" (rage) in 1978. Another magazine was called „Kalo Suraj" (Black Sun) and „Tod Fod (Destruction). „Dalit Kavita" the first anthology of Dalit poems was published in 1981, which has poets from different down- caste communities. It was instantly appreciated as its range of topics was impressive. It had not only new and militant voices from other backward communities and upper castes, especially poets who were earlier part of the literary protest movement, but also poets from Adivasis and other tribes. This was the reason, during the 1981 protests, the Gujarat government arrested Dalit poets along with Dalit Panthers activists and „Akrosh" was banned.

It was in the 1980s that Gujarati literature has witnessed a mutually reinforcing and supportive relationship between Dalit literature and Dalit empowerment. It was in this period that the term "Dalit" remained an integral part of the holistic literature and not exclusive. A number of poets who started voicing their angst were from the untouchable communities. This phase automatically entered into a more matured phase of Dalit prose. This was the first time that the writers from the Dalit communities only were recognized as Dalit writers.

\section{As Achyut Yagnik observes;}

" In the absence of a larger social movement in Gujarat covering all exploited and marginalized communities, the term „Dalit" lost its inclusiveness and openness.”

As it started with poetry, Gujarati Dalit literature was always dominated by poetry over any other form of writing. It constitutes the largest part of the corpus of Gujarati Dalit writings. In their search for self-identity and self-articulation, Dalit poets explored, again and again, their individual and collective past. The pain and anger of deprivation and oppression, of exploitation, marginalization, and humiliation, metamorphosed into punctuation marks in their poems. As Joseph Macwan writes in the preface of „Asmita"( identity),

" The history of Dalit literature of the last ten years is essentially the history of the expression of the agony experienced by the exploited."

Underlining this point of view he declared that he would not like to define Dalit literature in the framework of any ideology or evaluate it by any traditional aesthetic standards. Joseph Macwan was the first one to appreciate and encourage the authentic language used by the Dalits into his writings. In the process of selfexpression, Dalit writers constantly experimented with language as they mediate between three strands of Gujarati language representing their cultures- the literary-classical, the folk-colloquial and dialectical.

The social structures and its dynamism provided the exposure of more than one language cultures to the Dalit writers in Gujarati. Most of these writers belong to first or second generation migrant families who have moved from rural to semi-urban centers. That gave them access and exposure to the dialect of their native villages as well as the language of the urban cities. Higher education provided them an additional register of "standard" and „literary“Gujaratialso.

Folk elements also played an important role in the writings of Gujarati Dalits. In fact, in the beginning, Dalit writers started writing in the literary language. But eminent poets like Nirav Patel and Dalpat Chauhan created a parallel world by weaving together the literary and folk elements in the language. Other poets like Pravin Gandhi fused classical language and civilizational metaphors while Sahil Parmar introduced the contemporary spoken idiom of the urban chawls (ghettoes) with all its invective and insolence.

After poetry, Novel was the big thing that has happened to Gujarati Dalit literature. Joseph Macwan, Dalpat Chauhan, and Mohan Parmar, in their stories, weaved rural culture through local dialects. It provided a lot of authenticities to their writings. At the same time, the gradual process of "distancing" from the grass-roots on the one hand and recent 


\section{$\begin{array}{ll}\text { GAP BODHI TARU - } & \begin{array}{l}\text { An International Peer-Reviewed } \\ \text { Open Access Journal of Humanities }\end{array}\end{array}$}

„acquisition" of literary classical language and culture on the other created a palpable tension in their prose.

\section{REFERENCES:}

Achyut Yagnik, „Step Child“, Oxford University Press, New Delhi, 2004, P - 13

Achyut Yagnik, „Step Child“, Oxford University Press, New Delhi, 2004, P - 16

Achyut Yagnik, „Step Child“, Oxford University Press, New Delhi, 2004, P 26-27

Ibid. p-81

Ilaih, Kancha, Productive Labour. "Consciousness and History: The Dalitbahujan Alternative"." Subaltern Studies IX: Writings on South Asian History and Society: 165-200.

Joseph Macwan, „Step Child“ Angaliyat, , Tr. Rita Kothari, New Delhi, Oxford University Press, 2004. P- 1

Joseph macwan, Preface, „Asmita“, ed. Chandu Meheria, Gujarat: Khet Vikas parishad

K. M. Sherrif, „Eklvyas with Thumbs“, Pushpam Publications, Ahmedabad, 1999, p-9

Pathik Parmar, Tr. M.B.Gajjan. “Gujarati Dalit Poetry” in „Dalit Literature: A Critical Exploration“, Sarup and Sons, New Delhi. 2010. P- 141

Rita Kothari, „Step Child", Oxford University Press, New Delhi, 2004, P 9-10

Rita Kothari, „Step Child“, Oxford University Press, New Delhi, 2004, P -34

Shaid Amin and Dipesh Chakraborty, „Subaltern Studies IX: Writings on South Asian History and Society, Oxford University Press, new Delhi. 1997. P-169

Shanta Gokhle in The Hindu", the literary review, October 3, 2004 